\title{
CHARACTERIZATION OF STREPTOMYCETES WITH POTENTIAL TO PROMOTE PLANT GROWTH AND BIOCONTROL
}

\author{
Carla da Silva Sousa ${ }^{1}$; Ana Cristina Fermino Soares ${ }^{2 *}$; Marlon da Silva Garrido ${ }^{3}$ \\ ${ }^{1}$ UFRB - Centro de Ciências Agrárias, Ambientais e Biológicas - Programa de Pós-Graduação em Ciências \\ Agrárias - 44380-000 - Cruz das Almas, BA - Brasil. \\ ${ }_{3}^{2} U F R B$ - Centro de Ciências Agrárias, Ambientais e Biológicas \\ ${ }^{3}$ UFPE - Dep. de Energia Nuclear, 50740-540 - Recife, PE - Brasil. \\ *Corresponding author<acsoares@ufrb.edu.br>
}

\begin{abstract}
Studies with streptomycetes in biocontrol programs and plant growth promotion are presented as technological alternatives for environmental sustainable production. This work has the objective of characterizing six isolates of streptomycetes aiming the production of extracellular enzymes, indole acetic acid, capacity for phosphate solubilization, root colonization and growth under different $\mathrm{pH}$ and salinity levels. For detection of enzyme activity the isolates were grown in culture media with the enzyme substrates as sole carbon source. The root colonization assay was performed on tomato seedlings grown on $0.6 \%$ water-agar medium. Growth under different $\mathrm{pH}$ and salinity levels was evaluated in AGS medium with $1 \%, 1.5 \%, 2 \%, 2.5 \%$, and $3 \% \mathrm{NaCl}$, and $\mathrm{pH}$ levels adjusted to 5.0, 5.5, 6.0, 6.5, and 7.0. All isolates produced the enzymes amylase, catalase, and lipase, as well as indole acetic acid. With one exception (AC-92), all isolates presented cellulolytic and chitinolytic activity, and only AC-26 did not show xylanolytic activity. The isolates AC-147, AC-95, and AC-29 were the highest producers of siderophores. The isolates AC-26 and AC-29 did not show capacity for phosphate solubilization. All isolates colonized tomato roots in vitro, and AC-92 grew under all $\mathrm{pH}$ and salinity levels tested. The streptomycetes tested were considered as potential biocontrol and plant growth promotion agents.

Key words: actinomycetes, indole acetic acid, extracellular enzymes, siderophores
\end{abstract}

\section{CARACTERIZAÇÃO DE ESTREPTOMICETOS COM POTENCIAL PARA PROMOÇÃO DE CRESCIMENTO DE PLANTAS E BIOCONTROLE}

\begin{abstract}
RESUMO: Estudos com estreptomicetos em programas de biocontrole e promoção de crescimento de plantas são alternativas tecnológicas de produção sustentáveis ao ambiente. O presente trabalho teve como objetivo caracterizar seis isolados de estreptomicetos quanto à produção de enzimas extracelulares, ácido indolacético e sideróforos, capacidade de solubilização de fosfatos, colonização radicular e de crescimento em diferentes níveis de $\mathrm{pH}$ e salinidade. Para detectar a produção das enzimas extracelulares, os isolados foram cultivados em meio de cultura contendo os substratos dessas enzimas, como única fonte de carbono. Para determinar a capacidade de colonizar o sistema radicular, sementes de tomate foram cultivadas em meio ágar-água $0,6 \%$ e inoculadas com os estreptomicetos. $\mathrm{O}$ crescimento em diferentes níveis de salinidade e $\mathrm{pH}$ foram avaliados em meio de cultura AGS, com os níveis de $\mathrm{NaCl} 1 \%$, $1,5 \%, 2 \%, 2,5 \%$ e $3 \%$ e níveis de $\mathrm{pH}$ ajustados em 5,0, 5,5, 6,0, 6,5 e 7,0. Todos os isolados produziram as enzimas amilase, catalase e lípase, assim como o ácido indolacético. Todos os isolados apresentaram atividade celulolítica e quitinolítica, com exceção do AC-92. Somente o AC-26 não demonstrou atividade xilanolítica. Os isolados AC-147, AC-95 e AC-29 foram os maiores produtores de sideróforos. Os isolados AC-26 e AC-29 não demonstraram a capacidade in vitro de solubilizar fosfatos. Todos os isolados colonizaram as raízes das plântulas de tomateiro e AC-92 apresentou crescimento em todos os índices de salinidade e $\mathrm{pH}$ avaliados. Os estreptomicetos testados neste estudo foram considerados potenciais agentes de biocontrole de doenças e promoção do crescimento de plantas.

Palavras-chave: actinomicetos, ácido indolacético, enzimas extracelulares, sideróforos
\end{abstract}

\section{INTRODUCTION}

The actinomycetes, mainly those belonging to the Streptomyces genus, make up an important group of soil bacteria from the actinobacteria class. Several species of the Streptomycetaceae family are widely 
studied because of their ample capacity for production of secondary metabolites, such as antibiotics and extracellular enzymes (Inbar et al., 2005). These microorganisms are abundant in soils and act in the degradation of complex molecules as well as recalcitrant substances, especially cellulose, lignocellulose, xylan and lignin, that play an important role in soil organic matter decomposition processes (Petrosyan et al., 2003; Ding et al., 2004).

Besides acting as organic matter decomposers, these microorganisms have great potential as agents for control of plant pathogens (Hoster et al., 2005; Thirup et al., 2001) and/or for plant growth promotion (Nassar et al., 2003). This is due to their capacity to produce antibiotics, siderophores, enzymes that have antimicrobial activity, substances that promote plant growth, solubilization of phosphates and competition with plant pathogens for substratum and nutrients (Cattelan \& Hartel, 2000; Crawford et al., 1993).

Among the studies conducted in vitro aiming the selection of agents for biological control and plant growth, characteristics such as antagonistic activity against pathogens, capacity of colonizing the root system, production of siderophores, hydrolytic enzymes, and plant growth regulating substances are of fundamental importance (Cattelan, 1999). In addition, soil salinity and $\mathrm{pH}$ levels are abiotic factors which can interfere with the competitive capacity of these selected biological agents. Therefore, the tolerance for high salinity and low $\mathrm{pH}$ should be criteria for the selection of microorganisms aiming their adaptation in saline or acid soils, and their capacity to protect plants from these stressing environments (Drozdowicz, 1987). This study has the objective of morphologically and physiologically characterize six isolates of streptomycetes with potential to promote plant growth and to control plant pathogens.

\section{MATERIAL AND METHODS}

Six streptomycete isolates codified as AC-26, AC-29, AC-92, AC-95, AC-103 and AC-147 were evaluated. They came from the culture collection of the Phytopathology and Microbiology Laboratory of the Agricultural, Environmental and Biological Sciences Center, at Federal University of Recôncavo of Bahia (UFRB) State of Bahia, Brazil. These streptomycetes were isolated from rhizosphere soil of several crops by Lima (2002), and have been selected for plant growth promotion, control of tomato bacteria wilt (Lima, 2002), plant parasitic nematodes (Coimbra et al., 2005; Sousa et al, 2005; Sousa et al, 2006) and phytopathogenic fungi (Soares et al., 2006).

\section{Morphological characterization of streptomycete isolates}

Each streptomycete isolate was inoculated with a flamed-sterilized inoculating loop in three equally spaced streaks across the Petri plates with yeast extract-malte extract agar medium (YEM). Three sterile microscope slide covers were placed into the medium close to the culture streaks and the cultures were incubated at $28 \pm 2^{\circ} \mathrm{C}$ in a B.O.D. type incubator, in the dark. After seven, fourteen and twenty one days of incubation, the slide covers were carefully removed with the aid of sterile tweezers and put onto microscope slides with one drop of lactophenol with methyl-blue. The prepared slides were examined under a light microscope for observation of spore bearing hyphae and spore chains. Also, the mass colors of mature, sporulating aerial mycelium and of soluble pigments produced by the streptomycetes in the growth medium (YEM) were examined.

\section{Physiological characterization of streptomycete iso- lates}

The production of chitinases was determined according to Renwick et al. (1991) using colloidal chitin as substrate. The cellulolytic and xylanolytic activity was determined according to Lewis (1988) using agar-mineral salt medium (Tuite, 1969), containing cellulose and xylan as carbon sources, respectively. The production of catalase was determined in NYDA culture medium according to Mariano et al., (2000). The production of amylases was determined using agar starch medium with $0.2 \%$ soluble starch (Coon et al., 1957). The production of lipases was determined with Tween 80 as substrate (Sierra, 1957), and the indole acetic acid production according to Bric et al. (1991). The production of siderophores was evaluated according to Schwyn \& Neilands (1987). The ability to solubilize phosphates was determined by the method proposed by Katznelson \& Bose (1959).

To evaluate the ability of streptomycete isolates to colonize the root system of tomato seedlings grown in vitro, tomato seeds of the cultivar 'Santa Clara' were disinfected by immersion in ethanol (70\%) for 1 minute, followed by sodium hypochlorite (1\%) for 3 minutes, and six consecutive washings in distilled sterile water. The disinfected seeds were transferred, with the help of sterile tweezers, into test tubes containing agar-water culture medium with $0.6 \%$ agar. The tubes were sealed with plastic wrap and incubated in the dark at $28^{\circ} \mathrm{C}$, until root emergency (period of 3 to 4 days). After root emergency, streptomycete cultures grown in YEM medium for 10 days were scrapped with a flamed inoculating loop and the roots close to the surface of the growth medium were inoculated with a loop 
full of spores. The tubes with inoculated tomato seedlings were sealed with plastic wrap, and kept at room temperature and luminosity for daily observations of the extent of root colonization by the streptomycete isolates.

Growth of the streptomycete isolates was evaluated using AGS culture medium (Poter et al., $1960)$ at $\mathrm{NaCl}$ levels of $1.0 \%, 1.5 \%, 2.0 \%, 2.5 \%$, and $3.0 \%$. The control treatment used AGS medium with $0.5 \% \mathrm{NaCl}$ (standard growth conditions). Growth of streptomycetes was also evaluated using AGS culture medium at different $\mathrm{pH}$ levels $(5.0 ; 5.5 ; 6.0 ; 6.5$; and 7.0), adjusted with $1 \mathrm{M} \mathrm{HCl}$ and $0.5 \mathrm{M} \mathrm{NaOH}$, and a phosphate buffer. The control treatment used AGS medium with $\mathrm{pH}$ adjusted to $7.9 \pm 0.2$ (standard growth conditions).

\section{RESULTS AND DISCUSSION}

\section{Morphological characterization of streptomycete isolates}

In general, the streptomycete colonies showed sporulating aerial mycelium, firmly adhered to the solid growth medium, visible with a stereoscopic microscope (Table 1). In particular, the group Streptomyces shows dry, smooth or hairy colonies with airborne mycelium of different colours (Araújo, 1998). The colonies also produced soluble pigments of various colours. However, these phenotypic characteristics depend on the composition of the culture medium (Cross, 1989).

\section{Physiological characterization of streptomycete iso- lates}

All isolates, with the exception of AC-92, showed chitinolytic activity (Table 2 ). Chitinase production by theses streptomycete isolates could be a mechanism of biocontrol, most notably of phytopathogenic fungi, because the cell wall of these microorganisms consists of polysaccharides, such as chitin and glucan (Gooday et al., 1992).

With the exception of AC-92, the streptomycete isolates presented cellulolytic activity (Table 2). Cellulose is the most abundant polysaccharide (20-50\%) in the vegetable biomass, is formed by glucose chains forming a glycosidic or $\beta$-1,4-bond with C-4 of glucose, and may be degraded by various microbial enzymes such as cellulase (Murashima et al., 2002; Lynd et al., 2002). These microorganisms play an important role in the decomposition of organic matter and nutrient mineralization, which promote plant growth. They can also act as biocontrol agents on cellulose cell wall bearing (17-25\%) microorganisms such as Phytophthora and Pythium (Lima, 1998).

Only isolate AC-26 did not exhibit xylanolytic activity (Table 2). Xylan is the main constituent polysaccharide in the hemicellulose plant complex and consists of a main chain built by residues of xylopyranosyl linked by $\beta$-1,4-glycosidic bonds (Biely, 1993). Xylanase production by these streptomycete isolates suggests that these microorganisms act in the decomposition of organic compounds, releasing nutrients and other compounds which improve plant nutrition and growth.

All the studied isolates produced lipase, amylase, and catalase (Table 2). These enzymes also play an important role in promotion of plant growth and biological control of plant diseases. The lipids produced by plants and animals are complex esters of fatty acids and alcohols, with decomposition processes which are yet not well-understood (Moreira \& Siqueira, 2002). Starch is a mixture of two glucose polymers: amylose and amylopectin. It is the most important organic reserve compound of plants. Among the good starch decomposers are the actinomycetes which produce organic acids, $\mathrm{CO}_{2}$, and dextrin during the decomposition process (Moreira \& Siqueira, 2002).

Variability between the isolates was observed, with regard to their capacity to produce siderophores (Table 2). The best producers were the isolates AC147, AC-95, and AC-29. The production of siderophores concedes the microorganisms a competitive advantage in soil, since siderophores act as ironsequestering molecules secreted by microorganisms in response to low iron availability(Oliveira et al., 2003).

These compounds act on the outside of the cellular membrane, capturing iron molecules in solu-

Table 1 - Morphological characterization of streptomycete isolates.

\begin{tabular}{|c|c|c|c|c|c|}
\hline \multirow{2}{*}{$\begin{array}{l}\text { Streptomycete } \\
\text { isolates }\end{array}$} & \multicolumn{2}{|c|}{ Spore chains } & \multirow{2}{*}{ Aerial mycelium } & \multirow{2}{*}{ Colony color } & \multirow{2}{*}{ Pigment productior } \\
\hline & Format & Length & & & \\
\hline AC-26 & Spirals & Long & Present & White & Absent \\
\hline AC -29 & Spirals & Long & Present & Blue & Brown \\
\hline AC-92 & Spirals & Long & Present & Yellow-brown & Absent \\
\hline AC-95 & Spirals & Long & Present & Dark-gray & Absent \\
\hline AC- -103 & Spirals & Long & Present & White & Brown \\
\hline AC- 147 & Spirals & Long & Present & Light-gray & Absent \\
\hline
\end{tabular}

Sci. Agric. (Piracicaba, Braz.), v.65, n.1, p.50-55, January/February 2008 
tion, and binding then specifically to receptors of the complex localized in the membrane, through which they are absorbed, thereby making it available for plant growth (Neilands \& Leong 1986). These compounds act as growth promoters due to their ability to inhibit the proliferation of plant pathogens in the rizosphere, by depriving pathogens from this essential nutrient (Wei et al., 1996).

The production of growth promoting substances such as plant hormones is part of the metabolism of various bacteria associated with plants causing modifications in the morphology of roots, influencing nutrient and water absorption, and consequently promoting plant growth (Bashan \& Holgium, 1997). All studied streptomycetes produced indole-acetic acid (Table 2). Among the known biosynthetetic pathways of indole-acetic acid are the ones depending on tryptophan and the pathways independent of this aminoacid, which have as precursors, 3-indole-acetamine, 3-indole-pyruvate acid, and 3-indole-acetonitrile (Patten \& Glick, 1996). By producing plant hormones, microorganisms can stimulate plant growth in order to increase production of plant metabolites which can be utilized for microbial growth (Oliveira et al., 2003).

With the exception of AC-26 and AC-29, the streptomycetes presented the capacity for in vitro phosphate solubilization (Table 2). Biological phosphate solubilization is an alternative for improving the efficiency of natural phosphate utilization in agriculture. The main mechanism involved in the solubilization of phosphorus is related to organic acids synthesized by microorganisms, which also promote the acidification of the microbial cell and its environment. Among these, gluconic acid apparently is the most frequent solubilization compound. Other acids involved in the solubilization of phosphates are 2-ketogluconic acid, lactic acid, isovaleric acid, isobutyric acid, and acetic acid (Rodriguez \& Fraga, 1999). Besides the organic acids, the release of protons $\mathrm{H}^{+}$by the external cellular surface of ATPases, the production of chelating substances or the production of organic acids (sulfuric, nitric, and carbonic) can constitute alternative mechanisms for solubilization of organic phosphates (Oliveira et al., 2003). The main phosphorus providing mol-

Table 2 - Production of extracellular enzymes, siderophores, indole acetic acid, phosphate solubilization, and root colonization by streptomycete isolates.

\begin{tabular}{|c|c|c|c|c|c|c|c|c|c|c|}
\hline \multirow{2}{*}{$\begin{array}{l}\text { Streptomycete } \\
\text { isolates }\end{array}$} & \multicolumn{6}{|c|}{ Extracellular enzymes } & \multirow{2}{*}{$\begin{array}{l}\text { Siderophores } \\
*\end{array}$} & \multirow{2}{*}{$\begin{array}{c}\text { Indole } \\
\text { acetic acid }\end{array}$} & \multirow{2}{*}{$\begin{array}{l}\text { Phosphate } \\
\text { solubilization }\end{array}$} & \multirow{2}{*}{$\begin{array}{c}\text { Root } \\
\text { colonization } \\
* *\end{array}$} \\
\hline & Chitinase & Cellulase & Xylanase & Amylase & Catalase & Lipase & & & & \\
\hline AC- 26 & + & + & - & + & + & + & + & + & - & + \\
\hline AC-29 & + & + & + & + & + & + & +++ & + & - & + \\
\hline AC- 92 & - & - & + & + & + & + & + & + & + & + \\
\hline AC-95 & + & + & + & + & + & + & +++ & + & + & + \\
\hline AC- 103 & + & + & + & + & + & + & ++ & + & + & + \\
\hline AC- -147 & + & + & + & + & + & + & +++ & + & + & + \\
\hline
\end{tabular}

*Production of siderophores based on color intensity of culture medium: $(+++)$ intense production (yellow); (++) medium production (orange); $(+)$ weak production (red) and (-) without production (purple blue). **Presence of colonized roots $(+)$; absence of colonized $\operatorname{roots}(-)$.

Table 3 - Growth of streptomycete isolates in culture medium at different $\mathrm{pH}$ and $\mathrm{NaCl}$ levels.

\begin{tabular}{|c|c|c|c|c|c|c|c|c|c|c|}
\hline \multirow{2}{*}{$\begin{array}{l}\text { Streptomycete } \\
\text { isolates }\end{array}$} & \multicolumn{5}{|c|}{$\mathrm{pH}$ levels } & \multicolumn{5}{|c|}{ Salinity levels (\% $\mathrm{NaCl}$ in growth medium) } \\
\hline & 5.0 & 5.5 & 6.0 & 6.5 & 7.0 & 1.0 & 1.5 & 2.0 & 2.5 & 3.0 \\
\hline AC-26 & - & - & + & + & ++ & ++ & ++ & ++ & + & + \\
\hline AC-29 & ++ & +++ & +++ & +++ & +++ & ++ & ++ & ++ & + & + \\
\hline AC -92 & ++ & +++ & +++ & +++ & +++ & +++ & +++ & +++ & +++ & +++ \\
\hline AC-95 & + & ++ & +++ & +++ & +++ & ++ & ++ & + & + & + \\
\hline AC- 103 & + & + & ++ & +++ & +++ & ++ & + & + & + & + \\
\hline AC- 147165 & + & + & + & ++ & ++ & + & + & + & + & + \\
\hline
\end{tabular}

$(+++)$ intense growth; $(++)$ medium growth; (+) little growth; (-) without growth. 
ecules by means of mineralization are the nucleic acids, phospholipids and phosphate sugars that are easily degradable, and phytic acid, polyphosphates and phosphates which are mineralized more slowly. This mineralization is promoted by phosphatases or phosphohydrolases and classified as acid or alkaline according to the $\mathrm{pH}$ at which they show optimal activity. These enzymes can be either secreted through the plasma membrane or remain in the membrane (Rodriguez \& Fraga, 1999).

All streptomycete isolates colonized the root system of in vitro tomato seedlings. The constant exsudation of compounds, such as glutens, lecithins, flavonoids, and polysaccharides by the root cells and microorganisms, is responsible for the recognition between microorganisms and plants (Kijine et al., 1998) and the rhizosphere effect which culminates in the root colonization by microorganisms (Kortemaa et al., 1994).

In general, better growth of streptomycete isolates was observed at $\mathrm{pH}$ values above 6.5 (Table 3 ). Gava (1988) reported that the majority of actinomycetes isolated from rhizosphere and non-rhizosphere soil grow at a $\mathrm{pH}$ range varying from 6.5 to 8.0. Only AC-29 and AC-92 presented good growth, characterized by abundant mycelium, in culture media with $\mathrm{pH}$ between 5.0 and 5.5, which suggests that these are acid tolerant isolates (Moreira \& Siqueira, 2002). Research conducted by Coelho \& Drozdowicz (1998) in acid soils ( $\mathrm{pH} 4.9$ ) in the Brazilian Cerrado demonstrated the presence of a microbial population sufficiently numerous and rich in actinomycetes. The results of this work indicate the adaptability of these microorganisms under these environmental conditions, showing that they have a good ability to compete and survive in acid soils.

Growth of streptomycetes in culture medium AGS at different $\mathrm{NaCl}$ levels (varying between 1 and $3 \%$ ) indicates tolerance to salinity and an adaptability of these isolates to adverse growth conditions. Only isolate AC-92 showed satisfactory growth at all salinity levels (Table 3), indicating that it has the largest salinity tolerance. This may assist the competitive ability of this microorganism in adverse environments, giving it the best competitive ability and a possible role on plant protection to these environmental conditions. In this particular case the isolate showed rhizosphere competence.

The occurrence of actinomycetes in different ecosystems points out their metabolic diversity and the evolution of specific mechanisms for dispersion and adaptability under different environmental conditions. This metabolic diversity allows these microorganisms to survive in saline, acid, and high temperature environments, indicating their good ability to adapt to ad- verse environmental conditions (Araújo, 1998). These microorganisms show an elevated competitive ability in the presence of native microflora, permitting their establishment in environments in which they are introduced (Habe \& Uesughi, 2000). This could assist the establishment of plant species under adverse environmental conditions.

Based on the morphological and physiological characteristics of the streptomycete isolates, it can be concluded that these microorganisms present good potential as agents to promote plant growth and control of plant diseases.

\section{REFERENCES}

ARAÚJO, J.M. Estratégias para isolamento seletivo de actinomicetos. In: MELO, I. S; AZEVEDO, J. L. (Ed.). Ecologia microbiana. Jaguariúna: EMBRAPA - CNPMA, 1998, p.351367.

BASHAN, Y.; HOLGUIM, G. Azospirillum-plant relationships: environmental and physiological advances (1990-1996). Canadian Journal of Microbiology, v.43, p.103-121, 1997.

BIELY, P. Biochemical aspects of the production of microbial hemicellulases. In: COUGHLAN, M.P.; HAZLEWOOD, A. (Ed.) Hemicellulose and hemicellulases. London: Portland Press, 1993. p. 29-51.

BRIC, J.M.; BOSTOCK, R.M.; SILVERSTONE, S.E. Rapid in situ assay for indolacetic acid production by bacteria immobility on a nitrocellulose membrane. Applied and Environmental Microbiology, v.57, p.535-538, 1991.

CATTELAN, A.J. Métodos quantitativos para determinação de características bioquímicas e fisiológicas associadas com bactérias promotoras de crescimento vegetal. Londrina: Embrapa Soja, 1999, 36p.

CATTELAN, A.J.; HARTEL, P.G. Traits associated with plant growth-promoting rhizobacteria (PGPR). In: SOCIEDADE BRASILEIRA DE CIÊNCIA DO SOLO. Tópicos em Ciência do Solo. Viçosa: Sociedade Brasileira de Ciência do Solo, 2000. p.213-234.

COELHO, R.R.R.; DROZDOWICZ, A.G. The occurrence of actinomycetes in a cerrado soil in Brazil. Reviews Ecology Biology Soil, v.15, p.459-473. 1998.

COIMBRA, J.L.; GARRIDO, M.S.; SOUSA, C.S.; SOARES, A.C.F. Efeito de exsudatos de colônias Streptomyces sp. na mobilidade e mortalidade de Scutellonema bradys. Summa Phytopathologica. v.31, p.210-212, 2005.

COON, H.J.; JENNISON, M.W.; WEEK, O.B. Routine tests for the identification of bacteria. In: SOCIETY OF AMERICAN BACTERIOLOGISTS (Ed.) Manual of microbiological methods. New York: McGraw-Hill, 1957. p.239-262.

CRAWFORD, D. L.; LYNCH, J.M.; WHIPPS, J.L.; OUSLEY, M.A. Isolation and characterization of actinomycete antagonists of fungal root pathogens. Applied and Environmental Microbiology. v.59, p.3899-3905, 1993.

CROSS, T. Growth and examination of actinomicetes: some guidelines. In: WILLIANS, S.T.; SHARPE, M.E.; HOLT, J.G. (Ed). Bergey's manual of systematic bacteriology. Baltimore: Willians \& Wilkins, 1989. p.2340-2343.

DING, C.H.; JIANG, Z.Q.; LI, X.T.; LI, L.T.; KUSAKABE, I. High activity xilanase production by Streptomyces olivaceoviridis E86. Wold Journal of Microbiology \& Biotechnology, v.20, p.7-10, 2004.

DROZDOWICZ, A. G. Microbiologia do solo. In: ROITMAN, I.; TRAVASSOS, L. R.; AZEVEDO, J. L. (Ed.) Tratado de microbiologia. São Paulo. Manole, 1987. p.17-28. 
GAVA, C.A.T. Seleção de estreptomicetos para controle biológico de Ralstonia solanacearum e Erwinia carotovora. Rio de Janeiro: Universidade Federal do Rio de Janeiro, 1998. 114p. dissertação (Mestrado)

GOODAY, G.H., ZHU, W.Y., DONNELL, R.W. What are the roles of chitinases in the growing fungus. FEMS: Microbiology Letters, v.100, p.387-392. 1992.

HABE, M.H.; UESUGHI, C.H. Método in vitro para avaliar a capacidade colonizadora de bactérias em raízes de tomateiro. Fitopatologia Brasileira, v.25, p.657-660, 2000.

HOSTER, F.; SCHMITZ, J.E.; DANIEL, R. Enrichment of chitinolytic microorganisms: isolation and characterization of chitinase exhibiting antifungical activity against phytopathogenic fungi from a novel Streptomyces strain. Applied Microbiology and Biotechnology, v.66, p.434-442, 2005.

INBAR, E.; GREEN, S.J.; HADAR, Y.; MINZ, D. Competing factors of compost concentration and proximity to root affect the distribution of streptomycetes. Microbiology Ecology, v.50, p.73-81. 2005 .

KATZNELSON, H.; BOSE, B. Metabolic activity and phosphatedissolving capability of bacterial isolates from wheat roots, rhizosphere, and non-rhizosphere soil. Canadian Journal of Microbiology, v.5, p.79-85, 1959.

KIJINE, J. Leciting-enhanced acumulation of manganese limite Rhizobium leguminosarum cells on pea root hair tips. Journal of Bacteriology, v.170, p.2994-3000, 1988.

KORTEMAA, H.; RITA, H.; HAAHTELA, K.; SMOLANDER, A. Root-colonization abiliy of antagonistic Streptomyces griseoviridis. Plant and Soil, v.163, p.77-83, 1994.

LEWIS, K.J. Biological control mechanism of the mycoparasite Phytium oligandum Dreschler. Sheffield: University of Sheffield, 1988. 125p. PhD Thesis.

LIMA, L.H.C.; DE MARCO, J.L.; FELIX, C.R. Enzimas hidrolíticas envolvidas no controle por micoparasitismo. In: MELO, I.S.; AZEVEDO, J.L. (Ed.). Controle biológico. Jaguariúna: EMBRAPA-CNPMA, 1998. p.263-304.

LIMA, J.L. Seleção de actinomicetos para o controle biológico de Ralstonia solanacearum e promoção de crescimento de mudas de tomateiro. Cruz das Almas: Universidade Federal da Bahia, 2002. 63 p. Dissertação (Mestrado).

LYND, L.R.; WEIMER, P.J.; VAN, W. H.; ZYL, Y.I.S. Microbial cellulose utilization: fundamentals and biotechnology. Microbiology Molecular Biology Reviews, v.66, p.506-577, 2002.

MARIANO, R.L.R.; MICHEREFF, S.J.; SILVEIRA, E.B.; ASSIS, S.M.P.; GOMES, A.M.A. Isolamento de bactérias para testes de antagonismo. In: MARIANO, R.L.R. (Coord.). Manual de práticas em Fitobacteriologia. Recife: Universidade Federal Rural de Pernambuco, 2000. p.115-119.

MOREIRA, F.M.S.; SIQUEIRA, J.O. Microbiologia e bioquímica do solo. Lavras: UFLA, 2002. 626p.

MURASHIMA, K.A.; KOSUGI, Y.R.H.; DOI, R.H. Synergistic effects on crystalline cellulose degradation between cellulosomal cellulases from Clostridium cellulovorans. Journal of Bacteriology, v.184, p.5088-5095, 2002.

NASSAR, A.H.; EL-TARABILY, K.A.; SIVASITHAMPARAM, K. Growth promotion of bean (Phaseolus vulgaris L.) by a polyamine-producing isolate of Streptomyces griseoluteus. Plant Growth Regulation, v.40, p.97-106, 2003.
NEILANDS, J.B.; LEONG, S.A. Siderophores in relation to plant growth and disease. Annual Reviews in Plant Physiology, v. 37, p.187-208, 1986.

OLIVEIRA, A.L.M.; URQUiAGA, S.; BALDANI, J.I. Processos e mecanismos envolvidos na influência de microorganismos sobre o crescimento vegetal. Seropédia: Embrapa Agrobiologia, 2003. 40p.

PATTEN, C.L.; GLICK, B.R. Bacterial biosynthesis of indole-3acetic acid. Canadian Journal of Microbiology, v.42, p.207220, 1996.

PETROSYAN, P.; GÁRCIA-VARELA, M.; LUZ-MADRIGAL, A.; HUITRÓN, C.; FLORES, M.E. Streptomyces mexicanus sp., a xylanolytic micro-organism isolated from soil. Internacional Journal of Systematic and Evolutionary Microbiology. v.53, p.269-273, 2003.

POTER, J.N.; WILHELM, J.J.; TRESNER, H.D. Method for the preferential isolation of actinomycetes from soils. Applied Microbiology, v.8, p.174-178, 1960.

RENWICK, A.; CAMPBELL, R.; COE, S. Assessment of in vivo screening systems for potential biocontrol agents of Gaeumannomyces graminis. Plant Pathology, v.40, p.524$532,1991$.

RODRÍGUEZ, H.; FRAGA, R. Phosphate solubilizing bacteria and their role in plant growth promotion. Biotechnology Advances, v.17, p.319-339, 1999

SCHWYN, B.; NEILANDS, J.B. Universal assay for the detection and determination of siderophores. Analitycal Biochemistry, v.160, p.47-56, 1987.

SOARES, A.C.F.; SOUSA, C.S.; GARRIDO, M.S.; PEREZ, J.O.; ALMEIDA, N.S. Soil streptomycetes with in vitro activity against the yam pathogens Curvularia eragrostides and Colletotrichum gloeosporioides. Brazilian Journal of Microbiology, v.37, p.458-461, 2006.

SOUSA, C.S.; COIMBRA, J.L. SOARES, A.C.F.; GARRIDO, M.S.; PEREZ, J.O. Atividade nematicida de exsudatos de Streptomyces sp. sobre Meloidogyne incognita. Summa Phytopathologica, v.31, p.207-209, 2005.

SOUSA, C.S.; SOARES, A.C.F.; GARRIDO, M.S. Estreptomicetos no controle da meloidoginose em mudas de tomateiro. Pesquisa Agropecuária Brasileira, v.41, p.1759-1766, 2006.

SIERRA, S.A. Simple method for detection of lipolytic activity of microorganisms and some observations on the influence of the contact between cells and fatty substrates. Antonie van Laeuwenhoek, v.23, p.15-22, 1957.

THIRUP, L.; JOHNSEN, K.; WINDING, A. Succession of indigenous Pseudomonas spp. and actinomycetes on barley roots affected by the antagonistic strain Pseudomonas fluorescens DR 54 and the fungicide imazolil. Applied and Environmental Microbiology, v.67, p.1147-1153, 2001.

TUITE, J. Plant pathological methods: fungi and bacteria. Minneapolis: Burgess 1969. 239p.

WEI, G.; KLOEPPER, J.W.; TUZUN, S. Induced systemic resistence to cucumber disease and increased plant growth by plant growthpromoting rhizobacteria under field conditions. Phytopathology, v.86, p.221-224. 1996.

Received September 15, 2006

Accepted October 16, 2007 